\title{
PERCEPTION AND DETERMINANTS OF VASECTOMY ACCEPTANCE AMONG COUPLES OF CHILDBEARING AGE IN MOJOKERTO, EAST JAVA
}

\author{
Linda Presti Fibriana'), Tedjo Danudjo Oepomo²), Suminah3), AA Subiyanto4) \\ 1)Doctoral Program in Health Promotion/ Community Empowerment, \\ Sebelas Maret University \\ 2)Department of Obstetrics and Gynecology, Faculty of Medicine, \\ Sebelas Maret University \\ 3)Study Program in Agriculture, Sebelas Maret University \\ 4)Masters Program in Family Medicine, Sebelas Maret University
}

\begin{abstract}
Background: Indonesia is a country with the fourth largest population in the world. Its population growth rate is $1.49 \%$ per year. Acceptors of the family planning program among women of childbearing age is 60\%. However, male participants in using contraceptive, especially vasectomy, is low. Lack of knowledge and information on vasectomy may have caused fear, anxiety, and false perception. This study aimed to investigate the perception and determinants of vasectomy acceptance among couples of childbearing age in Mojokerto, East Java.

Subjects and Method: This was a qualitative study using grounded theory approach. A sample of 10 informants was selected for this study consisting of couples of childbearing age who were vasectomy acceptors and community members. Data were collected by in-dept interview and analyzed by Colaizzi method.

Results: Reasons for vasectomy acceptance included social responsibility, pity feeling for wife, and concern on future child welfare. There were no notable changes in physical appearance among the vasectomy acceptors. Sexual potency after vasectomy surgery did not weaken. However, social perceptions on vasectomy varied. Most community members believed that having children was an important issue and yet having prosperous family was equally important.

Conclusion: Vasectomy acceptors do not experience changes in physical appearance. Sexual potency and sexual life are not affected by vasectomy. The main reason for vasectomy is responsibility for future family welfare.
\end{abstract}

Keywords: vasectomy, acceptance, perception, determinant, couple of childbearing, community

Correspondence: Linda Presti Fibriana, Doctoral Program in Health Promotion/ Community Empowerment, Sebelas Maret University, Jl. Ir. Sutami 36A, Surakarta, 57126, Central Java. Email: Linda.fibriana@ yahoo.com. Mobile: +6281330569663 . 